\title{
Lozan Nüfus Mübadelesi Göçleri ve Türk Mübadillerin İskânı
}

\section{Lausanne Population Exchange Migration and the Habitation of Turkish Refugees}

\author{
Fahrettin TEPEALTI ${ }^{1}$ (1) \\ ${ }^{1}$ İstanbul Üniversitesi, Coğrafya Bölümü, İstanbul, Türkiye
}

ORCID: F.T. 0000-0002-6602-0640

\section{öz}

Lozan Konferansı́nda Türkiye ile Yunanistan arasında imzalanan bir sözleşme ile kesinlik kazanan Türk ve Rum nüfuslarının mübadelesi, her açıdan önemli sonuçlar doğurmuştur. Yüzbinlerce kişinin kendi anavatanı bildiği topraklardan zorunlu olarak çıkarılmasını ifade eden bu süreç, Cumhuriyet Türkiye'sinin çözmek zorunda kaldığı öncelikli sorunlardan birisi olmuştur. Türkiye'deki Rum ve Yunanistan'daki Türk azınlığı göçmen hâline getiren on yıllık bu süreç sonunda taraflar, mübadele sayesinde dinsel kimlik anlamında bütünlük sağlamıştır. Ancak giden göçmenlerin nitelikleri ve ülke ekonomisindeki değerleri göz önüne alındığında Türkiye'nin ciddi bir kayba uğradığı da bir gerçektir. Çünkü Türkiye'den Yunanistan'a göçen Rumlar ağırlıklı olarak ticaretle uğraşan şehirli nüfusu oluştururken, Yunanistan'dan Türkiye'ye göçen Türkler, tarımla uğraşan köylü nüfusu oluşturmaktaydı.

Bu makale, ilgili literatür taraması çerçevesinde mübadelenin taraflar açısından nedenlerini, Lozan'da ele alınışını ve uygulanma sürecini ele almaktadır. Konunun ana kısmını oluşturan “Türk Mübadillerin İskânı” bölümünde ise Türk Hükümetinin mübadillerin iskânı için yaptığı hazırlıklar ile iskân politikalarını etkileyen faktörler incelenmiştir. Ayrıca Türk mübadillerin iskânı, dağılış ilkesine göre incelenmiş ve başta iklim ve yüzey şekilleri olmak üzere coğrafi faktörlerin iskân uygulamaları üzerindeki etkisi açıklanmaya çalışılmıştır. Bu amaçla mübadillerin ülke geneline dağılışııı gösteren bir harita hazırlanmış ve iskân uygulamalarının başarı oranı değerlendirilmiştir.

Anahtar kelimeler: Türkiye-Yunanistan İlişkileri, Lozan Nüfus Mübadelesi, İskân Uygulamaları

\section{ABSTRACT}

The exchange of Turkish and Greek population, which became definite upon an agreement signed between Turkey and Greece at the Lausanne Conference, caused crucial consequences. This period, signifying a compulsory removal of people from their homeland, was a main issue for the Turkish Republic. At the end of ten-year process of transforming minorities in Turkey and Greece into immigrants, parties, through exchange, achieved religious identity integrity. However, considering the qualifications and the value of immigrants, it is a reality that Turkey suffered significant losses. Whereas Greeks migrating to Greece from Turkey were a tradesman urban population, Turks migrating from Greece to Turkey were a farmer peasant population.

This paper evaluates the exchange period under related literature, the tackling method in the Lausanne Conference and the implementation period. Moreover, the "Habitation of Exchanged Turks" section, constituting the core of subject, examines the preparations of the Turkish Government for the resettlement of refugees and factors affecting the policies. Furthermore, the resettlement of Turkish immigrants was examined under the distribution principle, and the effect of geographical factors, especially climate and surface shapes, on settlement practices is explained. For this purpose, a map showing the distribution of refugees throughout the country was prepared, and the success rate of settlement applications was evaluated.

Keywords: Turkey-Greece Relations, Lausanne Population Exchange, Habitation Implementations

Başvuru/Submitted: 30.07.2019 • Revizyon Talebi/Revision Requested: 02.11.2019 • Son Revizyon/Last Revision Received: 05.12 .2019 • Kabul/Accepted: $10.12 .2019 \cdot$ Online Yayın/Published Online: 27.12 .2019 


\section{EXTENDED ABSTRACT}

One of the societies living under Ottoman rule was the Greeks, who spread throughout the Empire, but concentrated mainly in Greece and the Aegean Region. The Greeks, who were influenced by the independence movements, whose influence was intensely felt in the 19th century, rebelled against the Ottoman Empire and continued to expand their sovereignty area with the support of the great states during the upcoming period. In this process, which continued until the August 30 Victory, there were various migration movements on both sides. The Greek population reached the highest level with the occupation of Anatolia by the Greek army, and after the resistance and success of the Turkish army, it started to turn towards Greece. Thereupon, Greece forced Turkish and Muslim population of its land to migrate to Turkey by increasing the pressure on them, and started the exchange process which had huge implications in every sense.

The population exchange, which was put into practice by Turkey and Greece to solve the minority problem, was concluded in the Lausanne Peace Conference, held in Switzerland upon the success of the National Struggle period.

As a result of the discussions at the Lausanne Conference, "the Convention and Protocol on the Exchange of the Greek and Turkish Peoples" was signed on 30 January 1923, which envisaged the exclusion of Turks from Western Thrace and Greeks in Istanbul. Under the Convention, "at the end of this migration movement, approximately 1.700 .000 people were exchanged. This figure comprises of 1.200.000 Turkish citizens who are Orthodox Greeks outgoing from Anatolia to Greece, and 500.000 Greek citizen Muslims coming from Greece to Turkey" (Ar1, 1995: 104)

The Ankara Government made various preparations to meet the needs of migrants coming through exchange. Despite all these preparations, migrants who came to Turkey, like the ones in Greece, experienced various difficulties originating in the implementation. The placement of immigrants was the most important of these. A significant portion of properties, which had to be allocated to the Turkish exchange, were either burned down or occupied by various people before the arrival of the exchange. This prevented the efficient functioning of the distribution of properties to the arriving exchange. Another important problem faced by the immigrants was related to the settlements. According to the terms of the Exchange Convention, the immigrants who came to Turkey had to be placed in the area the Greeks had vacated. This placement would be done in accordance with the climate and living conditions of the places the immigrants left. However, in order to start production as soon as possible, in some cases, it was decided to shift the exchanges to places where rail and other means of transport could go, not to the places vacated by the Greeks foreseen in the agreement.

When the distribution of migrants to geographical regions is examined, the Marmara Region is the first place where more than 260.000 migrants settled, with more than 100.000 in Thrace. The Aegean Region (13\%), the Black Sea Region (11\%), the Central Anatolia Region $(10 \%)$ and the Eastern Anatolia Region (2,5\%) followed the Marmara Region, which hosted more than half of the total population (58\%). The South-eastern Anatolia Region (0,5) has been the geographic region which received the least share of the exchange (Erdal, 2006: 352).

As a result of the resettlement implementation, it is seen that a significant part of the population could not have resettled in accordance with the purpose. Some exchanges were settled in places that were not compatible with their professions; some urban exchanges were settled in rural areas and some agricultural exchanges were settled in cities. In addition, the fact that migrants were settled in areas that they were not accustomed to caused social losses as well as economic losses.

The exchange yielded significant effects for both immigrants, and Turkey and Greece, in every field. At the end of this ten-year process of transforming the Greek minority in Turkey and the Turkish minority in Greece into immigrants, the parties, through the exchange, achieved integrity in the sense of religious identity. However, considering the qualifications of immigrants and their value to the country's economy, it is a reality that Turkey suffered a significant loss. Because, whereas, the Greeks who migrated to Greece from Turkey were mainly the urban population engaged in trade, the Turks who migrated from Greece to Turkey comprised the peasant population engaged in agriculture.

When the security and political conditions of the period are considered, the Lausanne population exchange was a necessary and successful application, paid by the states and nations, in order to solve the problem of minorities. 


\section{GÍRIŞ}

Osmanlı Devleti'nin 19. yüzyılda yoğun olarak toprak kaybetmesinin getirdiği sorunlardan birisi de çekildiği bölgelerde önemli miktarda Türk ve Müslüman nüfusun kalmasıdır. Özellikle Balkanlarda etkisini hissettiren bu sorun, en yoğun biçimde Yunanistan ile yaşanmıştır. Ayrıca Anadolu ve İstanbul'daki ciddi Rum nüfusun varlığı, tarafları nüfus değiş̧imi fikrine yönlendirmiş ve böylece mübadele süreci başlamıştır.

Türkiye ve Yunanistan'ın azınlıklar sorununu çözmek amacıyla uygulamaya soktukları nüfus mübadelesi, Milli Mücadele döneminin başarıya ulaşması sonrasında İsviçre'de toplanan Lozan Barış Konferansı'nda karara bağlanmıştır. Konferansa katılan diğer ülkelerin de desteklediği mübadele kararı, 30 Ocak 1923'te imzalanan "Yunan ve Türk Halklarının Mübadelesine İlişkin Sözleşme ve Protokol" ile kesinleşmiş ve hemen uygulanmaya başlanmıştır. Her iki devlet de mübadelenin uygulanması konusunda acele etse de karşılaşılan zorluklardan dolayı sürecin tamamlanması 1930'lu yılların ilk yarısını bulmuştur.

Mübadele kararı sonrasında Türkiye ve Yunanistan, sürecin yürütülebilmesi ve iskân faaliyetlerinin sorunsuz tamamlanabilmesi için çeşitli çalışmalar yapmalarına rağmen uygulamada ciddi sorunlarla karşılaşmışlardır. Tarafların henüz savaştan çıkmaları, toplumların yıpranmış olması ve ülke ekonomilerinin ciddi sıkıntılar içinde olması gibi sebeplerden dolayı mübadiller, gittikleri ülkelerde çeşitli sıkıntılarla karşı karşıya kalmıştır. Kişisel ve toplumsal travmalara neden olacak kadar büyük bir demografik ve sosyo-kültürel değişimi ifade eden mübadele süreci, iki toplumda da derin izler bırakmıştır.

\section{VERİ VE YÖNTEM}

Çalışmanın hazırlanmasında Devlet İstatistik Enstitüsü (DİE) verileri ile konuyu daha önce incelemiş ve kabul görmüş akademik çalışmalardan yararlanılmıştır. Türk akademisyenlerin makale ve kitaplarının yanı sıra, konuyu incelemiş yabancı araştırmacıların çalışmaları ve hatta Yunan bakış açısını yansıtan (Herkül) gibi yazarlar da konunun kıyaslamalı değerlendirilebilmesi için dikkate alınmıştır. Ayrıca Türk Tarih Kurumu, Atatürk Araştırma Merkezi ve T.C. Dışişleri Bakanlığı'nın yayın ve bilgilerinden de faydalanılmıştır.
Konu, yapısı gereği tarihi boyutu içinde değerlendirilmiş ve ilgili literatür taraması sonucunda ulaşılan veriler çerçevesinde açıklanmaya çalışılmıştır. Çalışmanın 1923-1933 dönemini kapsaması nedeniyle anket ve arazi çalışması gibi yöntemlere ihtiyaç duyulmamıştır. Çalışma konusu üç bölümde ele alınmış ve sonuç kısmında da mübadelenin genel olarak değerlendirilmesi yapılarak getirdiği kazanım ve kayıplar değerlendirilmiştir.

\section{TÜRK-YUNAN NÜFUS MÜBADELESININN NEDENLERI}

"Osmanlı Devleti'nde asırlarca çeşitli etnik ve dinî grupların bir arada yaşamasını sağlayan 'millet sistemi'1 on dokuzuncu yüzyılda milliyetçilik akımlarının etkisiyle sarsılmıştır” (Budak, 2010: 129). Özellikle Balkanlar'daki Huristiyan milletler üzerinde etkisini gösteren bu akım, Osmanlı İmparatorluğu'nun dağılışını hızlandırmış ve etkileri günümüze kadar uzanan ve “azınlıkları göçmenlere dönüştüren” (Yıldırım, 2016: 30) bir süreci başlatmıştır.

Osmanlı hâkimiyeti altında yaşayan toplumlardan birisi de İmparatorluğun geneline yayılmış olan ama özellikle şimdiki Yunanistan ve Ege Bölgesi'nde yoğunlaşan Rumlardı. 19. yüzyılda etkisini yoğun olarak hissettiren bağımsızlık hareketlerinden etkilenen Rumlar, Osmanlı Devleti'ne karşı ayaklanmış ve ilerleyen dönemde büyük devletlerin de desteğiyle hâkimiyet alanlarını sürekli olarak genişletmişlerdir. I. Dünya Savaşı sonrasında Yunanistan'ın Ege Bölgesi'ni işgal etmesiyle Anadolu'ya sıçrayan bu sıcak çatışma süreci, 30 Ağustos Zaferi ile Yunan ordusunun ülke topraklarından çıkarılmasıyla sona ermiş ve her anlamda büyük etkileri olan "Mübadele"2 süreci başlamıştır.

Mübadele fikrini ciddi anlamda ilk olarak 93 Harbi'nde (1877-1878) Ruslarla görüşen Saffet Paşa dile getirmiş (Şimşir, 1986: 202) ve Balkan sıradağlarının kuzeyindeki Müslümanların güneye, güneyindeki Bulgarlarınsa kuzeye gönderilmelerini, mal ve mülklerinin bir anlaşma ile tasfiyesini önermiştir. Bu o zaman için gerçekleşmese de ortaya atılmış bir fikir olarak yöneticilerin müstakbel stratejileri içerisinde yerini almıştır (Erdoğan ve Kaya, 2015: 174).

Balkan Savaşları sonrasında Osmanlı İmparatorluğu'nun her alanda büyük kayıpları olmuştur. Avrupa'daki topraklarının $\% 80$ 'ini ve toplam nüfusunun $\% 16$ 'sına karşılık gelen 4,2 milyon

1 Osmanlı Devleti'nin tebaası konumundaki toplulukları dini veya mezhebi farlılıklarına göre idare etme yöntemidir. İslam hukukuna ait bu kavramla ilgili daha fazla bilgi için bkz: (Eryılmaz, 1992).

2 Lozan Konferansı'nda imzalanan sözleşmeyle Türk ve Rum nüfusunun yer değiştirmesini ifade etmek için kullanılan Arapça kökenli bu kelime, "Değişim” anlamındadır. "Mübadil” ise mübadele edilmiş anlamına gelir. 
kişilik bir nüfusu kaybeden İmparatorluk, 500 yıldan fazla bir süredir hükmettiği toprakları terk etmek zorunda kalmıştır. Ayrıca yaklaşık 400.000'i Yunan, Sırp veya Bulgar vahşetinden kaçanlar olmak üzere 800.000'e yakın kişi de geri çekilen Osmanlı ordusunu izlemiştir (Zürcher, 2003: 1). Büyük miktardaki bu göç hareketleri, Balkan ülkelerinde nüfusun homojenleştirilmesi amacını ön plana çıkarmıştır. Bu dönemde bir ilk olarak, 1913 yılında Bulgaristan ile Osmanlı bir mübadele anlaşması imzalamış ve sınırdan 15 km'ye kadar olan bölgedeki toplam 90.000 civarında Bulgar ve Müslüman gönüllü olarak yer değiştirmiştir (Önder, 2000: 343).

“Birinci Dünya Savaşı'ndan Kurtuluş Savaşı'nın bitimine kadar geçen sürede giderek artan nüfus hareketlerini üç gruba ayırmak mümkündür:

1. Türkiye'den Türkiye dışına yönelik göçler

2. Türkiye'de işgalden kurtarılmış yörelere yönelik iç göçler

3. Türkiye dışından Türkiye'ye yönelik göçler” (Arı, 2012: 7).

İlk gruptaki göçler, genellikle Türkiye'yi terk eden Rumların gerçekleştirdiği göçleri; ikinci gruptaki göçler, işgalden kurtarılan yerlere yönelik ülke içi geri dönüş göçlerini ve üçüncü gruptaki göçlerse çoğunlukla Yunanistan'dan ülkemize gelen Müslüman ve Türk nüfusun yaptığı göçleri ifade etmektedir.

Anadolu'ya yönelik göç hareketleri bakımından Kurtuluş Savaşı'nın dönüm noktası olduğunu söylemek mümkündür. Yunan ordusunun Anadolu'yu işgali ile en yüksek seviyesine ulaşan Rum nüfus, Türk ordusunun gösterdiği direniş ve başarı sonrasında Yunanistan'a yönelmeye başlamıştır. Bu dönemde Anadolu'yu terk eden Rumların yaklaşı 850.000 kişiye ulaştığ ifade edilmektedir. Bunun üzerine Yunanistan da topraklarındaki Türk ve Müslüman nüfusa yönelik baskılarını artırarak onları Türkiye’ye göçe zorlamıştır (Arı, 1995). Bu nüfus hareketleri, göç eden insanların yanı sıra her iki devlet için de ekonomi başta olmak üzere her alanda ciddi sorunlara neden olmuştur. Ancak bu sorunların Yunanistan tarafinda daha fazla hissedildiği söylenebilir. Çünkü Türkiye'den göç eden Rum nüfus, ekonomik anlamda zaten sıkıntıda olan Yunan ekonomisine büyük mali yük oluşturmuştur (Belli, 2006: 89). Yunanistan bu sorunu ülkedeki Türk nüfusu Anadolu'ya gönderip yerlerine göçle gelen Rumları yerleştirerek çözmeyi amaçlamıştır. Lozan Konferansına giden Türk heyetinin azınlıkların mübadeleye tabi olmasına yönelik talimatlandırılmış olması (Bıyıkoğlu, 1987: 470) Türk tarafının da yaşadığı nüfus hareketlerine bağlı sorunları Yunan tarafı gibi mübadele yoluyla çözmeye hazır olduğunu göstermektedir. Osmanlı topraklarında yaşayan azınlıkların bağımsızlığa yönelik istekleri ve inşa edilmeye çalışılan ulus devlet fikri, bu dönemdeki nüfus hareketlerine yönelik tutumun temelini oluşturmuştur. Ayrıca ülke içinde istikrarın sağlanması ve büyük devletlerin müdahalesine zemin hazırlayan şartların ortadan kaldırılması da Türk yönetimini mübadele fikrine yönelten diğer nedenler olmuştur.

\section{LOZAN KONFERANSI'NDA NÜFUS MÜBADELESI SORUNU}

“Büyük Taarruz sonucu Yunan ordusu Anadolu'dan tümüyle çıkarılmış ve 11 Ekim 1922'de imzalanan Mudanya Mütarekesi ile Türk-Yunan çatışması sona ermiştir. Aynı zamanda TBMM'nin varlığını kabul etmek zorunda kalan... İtilaf Devletleri ile TBMM Hükümeti arasında bir barış antlaşmanın yapılması kararlaştırılmıştır" (Budak, 2010: 131). Bu amaçla İsviçre'nin Lozan kentinde bir konferans düzenlenmiş ve Türkiye'nin birçok önemli sorunu ile birlikte Türk-Yunan nüfus mübadelesine de çözüm aranmıştır.

Görüşmeler sırasında Türk tarafı, İstanbul dâhil kendi topraklarındaki tüm Rum nüfusun mübadeleye tabi olmasını istemiş ve Batı Trakya'da yaşayan Türk nüfusun ise kapsam dışında tutulmasını talep etmiştir. Yunan tarafı ise "yüzyıllardan beri Yunan halkının ideolojik ve kültürel merkezi olan İstanbul'u mutlak anlamda terk etmemek için mübadelenin sınırlarını dar tutmak" (Oran, 2002: 330) amacıyla hareket etmiştir. Burada her iki ülke için de dikkati çeken temel amaç, kendi içindeki azınlıklardan mümkün olduğunca kurtulmak ve muhatabının sınırları içindeki kendi soydaş ve dindaşlarınınsa yerinde kalmasını sağlamaktır. Böylece her iki ülke de gönderdiği azınlıklar sayesinde elde ettikleri yerleşim alanlarına göçle gelen insanlarını yerleştirerek mübadeleden kaynaklanan sorunlarını en az maliyetle çözmeyi amaçlamıştır.

"Mübadele konusu, Lozan Barış Konferansı sırasında Ülke ve Askerlik Sorunları Komisyonu'nun 1 Aralık 1922 oturumunda ele alınmıştır ve Nansen'in ${ }^{3}$ yeni raporu da bu oturumda okunmuştur" (Bozdağl1, 2014: 16). Nansen, raporunda mübadelenin her iki ülke için de en iyi çözüm olduğunu

3 Milletler Cemiyeti'nin konu ile ilgili görevlendirdiği Norveçli Dr. Friedtjof Nansen, Kuzey Kutbu kâşiflerinden birisidir. Ayrıca hekim de olan Nansen, insani konularda tanınan bir isimdir ve en son işi olan Rus Savaş Esirleri Yüksek Komiserliği ile tarafların sempatisini kazanmıştır. bkz:,(Macar, O.D. ve Macar, E., 2010). 
belirtirken, aksi halde ekonomik sonuçların taraflar için felakete neden olacağını söylemiş ve bu yüzden azınlıkların değişiminin en etkili çözüm olacağını savunmuştur (Arı, 2012: 16).

Türkiye ve Yunanistan mübadele konusunda anlaşmış olmasına rağmen içerik konusunda bazı görüş ayrılıkları yaşanmıştır. Mübadelenin zorunlu mu yoksa gönüllü mü olacağ bunlardan birisidir. Yunanistan gönüllü mübadeleyi savunurken, Türk tarafı zorunlu mübadeleyi istemiştir. İngiltere Dışişleri Bakanı Lord Curzon'un da Türk tarafinı desteklemesiyle "gönüllülük" esasına göre başlayan mübadele görüşmeleri, uygulamanın süresinin uzayacağı ve nüfus değişiminin eşzamanlı yapılmasının zorlaşacağı gerekçeleriyle "zorunluluk" esasına dönüşmüştür. Taraflar arasında yaşanan bir diğer sorunsa mübadelenin kapsayacağı nüfusun sınırları konusunda olmuştur. "Komisyondaki Türk üyeler, İstanbul'daki Rumların da zorunlu mübadelesi konusunda 1srar etmiş, Yunanlılar da bu teklife şiddetle karşı çıkmışlardır. Türk üyeler Batı Trakya Müslümanlarının mübadelesini istemediği için onlar da İstanbul Rumlarının mübadeleden muaf tutulması teklifinde bulunmuşlardır"'(Kodaman, 2008: 11). Tartışmalar sonucunda 30 Ocak 1923 tarihinde Batı Trakya'daki Türkler ile İstanbul'daki Rumların mübadele kapsamı dışında tutulmasını öngören "Yunan ve Türk Halklarının Mübadelesine İlişkin Sözleşme ve Protokol” imzalanmıştır (Kodaman, 2008: 15).

Sözleşmenin ilk maddesinde mübadelenin kimleri kapsadığ 1 ifade edilmiştir:

"Türk topraklarında yerleşmiş Rum Ortodoks dininden Türk uyrukları ile Yunan topraklarında yerleşmiş Müslüman dininden Yunan uyruklarının, 1 Mayls 1923 tarihinden başlayarak, zorunlu mübadelesine girişilecektir. Bu kimselerden hiç biri, Türk Hükümetinin izni olmadıkça Türkiye'ye ya da Yunan Hükümetinin izni olmadikça Yunanistan'a dönerek orada yerleşemeyecektir" (Soysal, 2000: 185).

Sözleşmenin 2. maddesinde ise ilk maddeye getirilen istisnalar belirtilmektedir:

"Birinci maddede öngörülen mübadele:

a) İstanbul'da oturan Rumları (İstanbul'un Rum ahalisini);

b) Batı Trakya'da oturan Müslümanları (Batı Trakya'nın Müslüman ahalisini) kapsamayacaktır.
1912 Kanunuyla sinırlandirlldiğ biçimde, İstanbul Şehremaneti daireleri içinde, 30 Ekim 1918 tarihinden önce yerleşmişs (établis) bulunan bütün Rumlar, Istanbul'da oturan Rumlar sayılacaklardır. 1913 tarihli Bükreş Antlaşması'nın koymuş olduğu sinır çizgisinin doğusundaki bölgeye yerleşmiş tüm Müslümanlar Batı Trakya'da oturan Müslümanlar sayllacaklardir" (Soysal, 2000: 185).

Türkiye 2. maddede belirtilen istisnalar dışında, mübadele kapsamında olduğu halde bir kısım Rum azınlığı mübadele kapsamı dışında tutmuştur. Bu gruptakileri, "özel nedenlerle istisna edilenler" ve "askeri nedenlerle istisna edilenler" olmak üzere ikiye ayırmak mümkündür. Ayrıca bunların dışında bir de “mübadelesi tecil olanlar” vardır (Öksüz, 2000: 759). “Özel nedenlerle istisna edilenler, gerek Türk gerekse mübadeleye tabi olmayan Gayr-i Müslim erkeklerle evlilik yapmış olan Rum asıllı kadınlar.. ile 'Mübadele Sözleşmesi'nden önce ihtida (Müslümanlığı kabul etme) etmiş" (Öksüz, 2000: 759) kişilerden oluşmaktadır. Askeri nedenlerle istisna edilenler ise Kurtuluş Savaşı yıllarında insani ve askeri yardımı görülen Rumlardır. Yunanlılar tarafindan Türklere yapılan feci uygulamalara engel olarak birçok kişiyi kurtaranlarla isyan çıkaran Rumlar hakkında bilgi verenler de bu gurup içinde değerlendirilmiştir. Mübadelesi tecil olanlarsa kimsesiz, sakat ve marazlı kişilerden oluşmaktadır (Öksüz, 2000: 760-61).

Mübadele Sözleşmesi'nin 5. maddesi mübadele kapsamına giren kişilerin mülkiyet haklarını ve alacaklarını, 8. maddesi ise mübadillerin her çeşit taşınır mallarını herhangi bir vergi alınmaksızın yanlarında götürebilmelerini teminat altına almaktadır (Oran, 2002: 332). Taşınır malların tümünü ya da bir kısmını yanında götüremeyecek olan mübadillerse bunları yerlerinde birakabilecektir. Bu durumda yerel makamlar da ilgili mübadilin gözü önünde bu malların dökümünü yaparak değerini belirlemekten sorumlu olacaklardır (Bozdağl1, 2014: 21).

Mübadillerin yanında götüremediği bu malların tasfiyesi, Karma Komisyon ${ }^{4}$ tarafından gerçekleştirilecektir:

"Bu tasfiyeler sonucu ortaya çıkacak para tutarı, ilke olarak tasfiyenin yapıldığı ülke hükümetinin, göç edilen ülke hükümetine karşı bir borcu kabul edilerek göç eden kişiye, göç ettiği ülkede ardında birakttğ mallarla eş değer ve nitelikte mal alması sağlanacaktır. Tasfiye işlemi sona erdiğinde, eğer hükümetlerden

4 Karma Komisyon, mübadeleyi denetlemek, kolaylaştırmak, taşınır ve taşınmaz malların tasfiyesine girişmek ve taşınmazlara değer biçmekte tam yetkili olacaktır. 11 üyeli komisyon, 4 Türk, 4 Yunan ve 3'ü de I. Dünya Savaşı'na girmemiş ülke temsilcisinden oluşacaktı. Komisyon başkanlığını tarafsız üyeler sıra ile yapacaktı. bkz: (Erdoğan ve Kaya, 2015: 176). 
biri ötekine borçlu kalırsa, bu borç peşin olarak ödenecektir. Borçlu ülke süre isterse, belli koşullarda taksit de yapılacaktır (md. 9-14)" (Oran, 2002: 333).

Türkiye ile Yunanistan arasındaki mübadeleyle ilgili çözümlenemeyen konularsa, tarafların 10 Haziran 1930 tarihinde imzaladığı Ankara Antlaşması ile hükme bağlanmıştır (Bozdağlı, 2014: 24). Ankara Antlaşmasından sonra Türkiye ile Yunanistan arasında yapılan “Muhtelit(Karma) Komisyon'un Kaldırılmasına Dair Antlaşma ile de mübadele işlemleri 19 Ekim 1934 tarihinde resmi olarak sona ermiştir" (Kodaman, 2008: 29).

\section{NÜFUS MÜBADELESININ UYGULANMASI VE TÜRK MÜBADİLLERİN İSKÂNI}

Lozan Mübadele Sözleşmesi sonucunda İstanbul, Gökçeada ve Bozcaada'da yerleşik Rumların haricinde tüm Türkiye'de yerleşik Rumlar Yunanistan'a; Batı Trakya haricinde Yunanistan topraklarında yerleşik tüm Müslümanlarsa Türkiye'ye gönderilmiştir. $\mathrm{Bu}$ göç hareketinin sonunda Anadolu'dan Yunanistan'a yaklaşık 1.200.000 Türkiye uyruklu Ortodoks Rum gitmiştir (Ar1, 1995: 104). Lozan'da oluşturulan Karma Komisyonun verdiği rakama göre, Yunanistan'dan Türkiye'ye gelen Yunanistan uyruklu Müslüman göçmen sayısı ise 388.146 (Ladas, 1932: 706) olmuştur. ${ }^{5}$ Böylelikle 1923 yılında Gümülcine, İskeçe ve Dedeağaç'ı kapsayan Batı Trakya'da kalan Türk azınlık nüfusu 129.000'e (ABTTF, 2019), Türkiye'deki Rum nüfus ise 120.000'e (Milliyet, 2012) düşmüştür. ${ }^{6}$

Lozan nüfus mübadelesi üç özelliğiyle dikkati çekmektedir. Birincisi, mübadeleye esas nüfusun belirlenmesinde kullanılan ana kriter dindir ve buna uygun olarak mübadeleye tabi tutulanların dil, kültür veya etnik köken farkları göz önünde bulundurulmamıştır. $\mathrm{Bu}$ nedenle Mübadele Sözleşmesi'nde Yunanistan'dan getirtilecek olan nüfus için "Türk" ifadesi kullanılmamış; "Yunan arazisinde sâkin Müslüman dininde bulunan Yunan tebaası" nitelemesi kullanılmıştır (Babuş, 2006: 128). Oysaki "dindaş" sıfatıyla gelen mübadiller, dil, kültür ve sosyal yaşantı anlamında kendi içlerinde büyük farklılıklar göstermekteydi. İkinci önemli özellik ise "sözleşmenin geriye dönük olmasıdır. Mübadele sadece 1922 yılı itibariyle göç edenleri değil, 1912 yılından beri göç edenleri kapsamaktadır. Mübadelede dikkati çeken üçüncü özellik de göçün isteğe bağlı değil, zorunlu olmasıdır" (Zürcher, 2003: 4). Bu yönüyle mübadele göçü, çok büyük kişisel ve toplumsal yaralara, iskân sorunlarına ve ekonomik maliyetlere neden olmuş travmatik bir uygulamadır. ${ }^{7}$ Ancak tüm bu özelliklerine rağmen zorunlu olması göçü kolaylaştırmış ve uygulamayı hızlandırmıştır.

Anadolu'dan göç eden Rum nüfus (1,2 milyon), toplam nüfusu 5,5 milyon olan Yunanistan'da çok ciddi sorunlara neden olmuştur. Göçmenler ilk olarak kamplara, daha sonra kasaba ve ilçelere ama özellikle Atina ve Selanik gibi büyük şehirlere yerleştirilmiştir (Zürcher, 2003: 4). Gelen göçmenlerin ülke nüfusuna oranının oldukça yüksek olması zaten kötü durumda olan ülke ekonomisine ilave bir yük bindirmiştir. "Yunanistan'ı terk eden Müslümanlardan kalan yerlere sadece Rumların \%40'1 yerleştirilebilmiş, bu durum göçmenlerin hayat şartlarının daha da kötüleşmesine yol açmıştır" (Blanchard, 1925: 453). Tüm bunlara önemli bir bölümü zaten isteksiz gelen mübadillerin yaşadığı şiddetli uyum sorunu da eklenince, "bu göçmenlerin çoğu Avrupa ve Amerika'ya göç etmek zorunda" (Bozdağl1, 2014: 25) kalmıştır.

Ankara Hükümeti, mübadele ile gelen göçmenlerin ihtiyaçlarını karşılayabilmek için çeşitli hazırlıklar yapmıştır. $\mathrm{Bu}$ amaçla Rumlardan kalan yerleşim mekânlarını oturulabilir hale

5 Yunanistan'dan Türkiye'ye gelen mübadillerin sayısını farklı veren kaynaklar da mevcuttur. Örneğin Arı'ya göre bu sayı 500.000 civarındadır (Arı, 1995: 104).

6 Batı Trakya'daki Türk nüfusu, günümüzde ancak 150.000'e ulaşabilmiştir. Türk azınlığa uygulanan baskılar nedeniyle bölge dışına yaşanan göçlerin bir sonucu olan bu sayısal değişim, Türk azınlığın bölgedeki nüfus ve toprak sahipliği oranı da etkilemiştir. 1920'li yıllarda \%65 olan Türk azınlığın Batı Trakya nüfusuna oranı, günümüzde \%30'lara, toprak sahipliği oranı da aynı dönemde \%84'ten \%25'e kadar düşmüştür (T.C. Dışişleri Bakanlığı, 2019). Türkiye'deki Rum azınlığın nüfusu ise TÜiK' in etnik temelli sayım yapmaması nedeniyle tam olarak bilinmemekte ve tahminler üzerinden yorumlar yapılmaktadır. Örneğin Fener-Rum Patriği Bartholomeos'a göre Türkiye'deki Rum nüfus, günümüzde 3.000'e kadar düşmüştür (Milliyet, 2012). "Heybeliada Aya Triada Manastırı Başrahibi ve Bursa Metropoliti Dr. Elpidophoros Lambriniadis ise 2006 yılında kilise toplumları aracıllğıyla yapılan bir sayıma göre İstanbul, Gökçeada ve Bozcaada'daki Rum nüfusunun 4.700” (Tan, 2014) civarında olduğunu belirtmiştir.

7 Mübadele öncesi ve sonrası dönemler her iki millet tarafından yaşadıkları acıların bilinmesi amacıyla yazılı ve sözlü olarak ifade edilmiş, yaşanan sıkıntıların gelecek kuşaklar tarafından bilinmesi amaçlanmışır. Doğal olarak her iki taraf da olayları kendi lehine olacak şekilde dile getirmiştir. Yunan tarafının bu süreçte yaşadıklarını anlatan bir kaynak olarak bkz: (Herkül, 2014). Ayrıca bu konuda Yunan tarafının Türk tarafına göre daha iyi organize olduğunu söylemek mümkündür. Örneğin kendi alanında ilk olan Lozan Mübadilleri Vakfı, 2000 yılının sonunda kurulmuştur. Oysaki Yunan tarafındaki benzer örgütlenmelerin tarihi çok daha eskidir. 


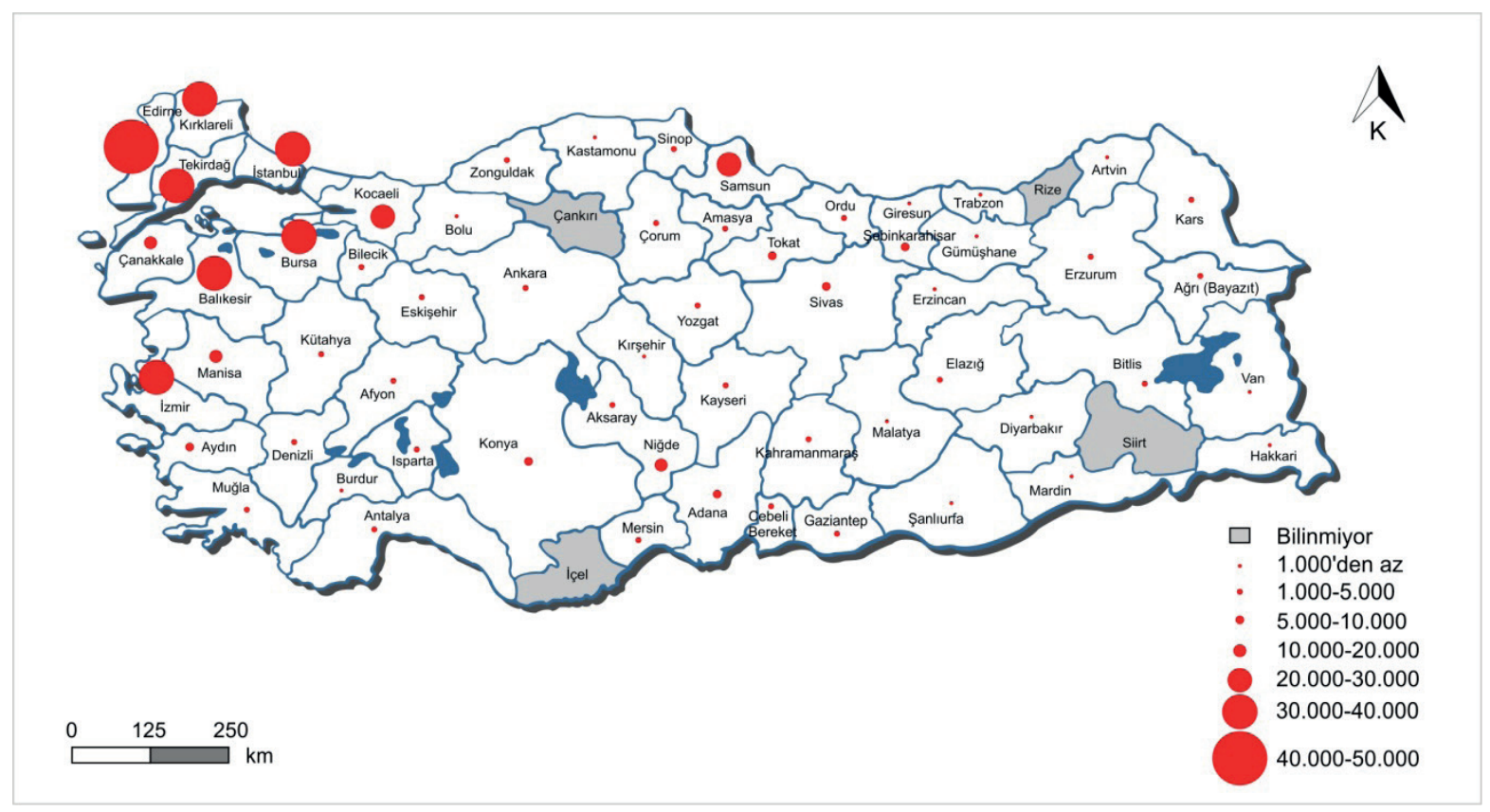

Şekil 1: İskân Edilen Türk Mübadillerin Dağılışı (1923-1927). ${ }^{8}$

Figure 1: The Distribution of Settled Exchanged Turkish Immigrants (1923-1927).

getirmek, üretim araçlarını temin etmek ve hayatlarını idame ettirebilir k1lmak amacıyla "13 Ekim 1923’te Mübadele İmar ve İskân Vekâleti (MiIV) kurulmuştur” (İskân Tarihçesi, 1932: 1317). Ancak yetki çatışmaları nedeniyle verimli bir şekilde çalışamayan MïV, 11 Aralık 1924'te lağvedilerek görevleri Dâhiliye Vekâleti'ne bağlı olarak kurulan İskân Umum Müdürlüğü'ne devredilmiştir ( Erdoğan ve Kaya, 2015: 183).

Hükümet tarafından Türk Mübadillerin kabulü, sevki ve iskânına yönelik çeşitli düzenlemeler yapılmıştır:

"Muhacirlerin çıkarılacakları iskelelerde lazım gelen sıhhî tedbirler ve karantina alanlart hazirlanacakttr. Yunanistan iskelelerinden Türkiye hudutlarına gönderilen İslâm muhacirler, aslî memleketleri itibartyla Türkiye'nin hangi yerleşim mıntıkasına tayin edilmişseler o bölgenin iskelelerine çıkarılacaklardır. Mübadillerin çıkarılacakları iskelelerde bunların kabul işleri ve sevk işleriyle meşgul olmak üzere en büyük mülk̂̂ idarecinin başkanlığında bir komisyon teşkil olunacaktır. İsbu komisyon, gelecek ahalinin hüviyet ve evrakını inceleyecek; içlerinde anarşist, casus ve millî harekette Yunanlılarla birlikte mücadele etmiş vb. faaliyette bulunanları ayıklayacaktır. Kabullerinde mahzur görülmeyenlere kayttlarıyla kendilerine ayrılan mintıkalara göre vesikaları verilecektir. Kabullerine karar verilen muhacirlerin tayin olunan mintıkalara sevk, iaşe ve yerleştirilme işleri muhacir ve mülteci komisyonları marifetiyle yerine getirilecektir. Kabullerinde mahzur görülenlerse hudut dlşı edilecek ve bağlı bulundukları memlekete iade edilecektir" (Güner, 2015: 1456).

"Servet sahibi olup Hükûmet'ten hiçbir surette yardım talep etmeyenler Türk ise serbest birakllacak ve kendi imkânlart ile memlekette yerleşeceklerdir. Türk olmayan, Hükûmetin göstereceği mintıkada yerleşmeyi kabule mecbur olup, kabul etmeyenler huduttan ihraç olunacaktır. Muhtaç muhacirlerden Hükûmet'in kabul ettiği mıntıkaya gitmeyenler veya ellerindeki vesikalarla belirlenen mintıkalara gitmeyenler, muhacirlik hakkından düşmüs olacaklardır. Gelen ahali dağllk veya sahil ahalisinden olmalarına göre araziye yerleşecek; çiftçi, bağcl, tütüncü, zanaatkâr gibi vasiflara uygun bölgelerde yerleşmede muvafakat aranacaktır. Yunanistan'dan mübadele neticesinde gelen ahalinin biran evvel memleketimizde üretici hâline geçmesi lüzumlu olmakla birlikte büyük çoğunluk köylerde yerleşime itina edilecektir... Ancak herhangi bir Türk kasaba ve köyünde lisan ve âdetleri başka diğer bir urka mensup muhacirlerin oranı \%20'yi asla geçmeyecektir" (Güner, 2015: 1457-1458).

Tüm bu hazırlıklara rağmen Türkiye'ye gelen mübadiller de Yunanistan'dakiler gibi uygulamadan kaynaklı çeşitli zorluklar yaşamıştır. Göçmenlerin yerleştirilmesini güçleştiren en önemli

8 Devlet İstatistik Enstitüsü (Behar, 1996: 63) verileri esas alınarak hazırlanmıştır. 
Tablo 1. İllere Göre İskân Edilen Mübadil Sayıları (1923-1927) (Devlet İstatistik Enstitüsü; Behar, 1996: 63)

Table 1. Number of Exchanged Immigrants Settled by Province (1923-1927) (State Institute of Statistics; Behar, 1996: 63)

\begin{tabular}{|c|c|c|c|c|c|c|c|}
\hline il & Mübadil Sayısı & il & Mübadil Sayısı & il & Mübadil Sayısı & il & Mübadil Sayısı \\
\hline Adana & 8440 & Çanakkale & 11638 & Isparta & 1175 & Mersin & 3330 \\
\hline Afyon & 1045 & Cebeli Bereket & 2944 & İstanbul & 36487 & Muğla & 4968 \\
\hline Aksaray & 3286 & Çorum & 1570 & İzmir & 31502 & Niğde & 15702 \\
\hline Amasya & 3844 & Denizli & 2728 & Kars & 2512 & Ordu & 1248 \\
\hline Ankara & 1651 & Diyarbakır & 484 & Kastamonu & 842 & Samsun & 22668 \\
\hline Antalya & 4920 & Edirne & 49441 & Kayseri & 7280 & Şanlıurfa & 290 \\
\hline Artvin & 46 & Elazığ & 2124 & Kırklareli & 33119 & Şebinkarahisar & 5879 \\
\hline Aydın & 6630 & Erzincan & 116 & Kırşehir & 193 & Sinop & 1189 \\
\hline Balıkesir & 37174 & Erzurum & 1095 & Kocaeli & 27687 & Sivas & 7539 \\
\hline Bayazıt & 2856 & Eskişehir & 2567 & Konya & 5549 & Tekirdağ & 33728 \\
\hline Bilecik & 4461 & Gaziantep & 1330 & Kütahya & 1881 & Tokat & 8218 \\
\hline Bitlis & 3360 & Giresun & 623 & Malatya & 76 & Trabzon & 404 \\
\hline Bolu & 194 & Gümüşhane & 811 & Manisa & 13829 & Van & 275 \\
\hline Burdur & 448 & Hakkâri & 310 & Maraş & 1143 & Yozgat & 1635 \\
\hline Bursa & 34543 & Hatay & 1037 & Mardin & 200 & Zonguldak & 1285 \\
\hline
\end{tabular}

sorun, Rumlar tarafından terk edilen mülklerin durumuydu. Türk mübadillere tahsis edilmesi gereken söz konusu mülklerin önemli bir kısmı, ya yakılıp yıkılmış ya da mübadillerin gelişinden önce çeşitli insanlar tarafından işgal edilmişti. Bu durum, gelen mübadillere mal dağıtımının etkin işleyişini engellemiştir (Yıldırım, 2016: 206). Mübadillerin yaşadığı bir diğer önemli sorunsa yerleştirildikleri bölgelerle ilgiliydi. “Mübadele Antlaşması şartlarına göre, Türkiye'ye gelen göçmenlerin Rumların boşalttıkları alanlara yerleştirilmesi gerekmekteydi. $\mathrm{Bu}$ yerleştirme, göçmenlerin terk ettikleri yerlerin iklim ve hayat şartlarına uygun olarak yapılacaktı" (Bozdağl1, 2014: 26). Ancak bir an önce üretime geçilmesi amacıyla mübadillerin bazı durumlarda anlaşmada öngörülen Rumların boşalttığı yerlere değil "kıyı, kent, kasaba ve köylerden başlanarak, demiryolu ve diğer ulaşım araçlarının gidebildiği yerlere kaydırılması yoluna gidilmiştir” (Kodaman, 2008: 23).

Mübadil iskânının en yoğun olduğu sahalar, Rumların terk ettiği yerler olarak göze çarpmaktadır. Coğrafi ve kültürel yakınlıktan dolayı mübadil iskânı sırasıyla Edirne, Balıkesir, İstanbul, Bursa, Tekirdağ, Kırklareli, İzmir ve Kocaeli illerinde yoğunlaşmıştır.

Mübadillerin coğrafi bölgelere dağılışına bakıldığında 100.000'den fazlası Trakya'da olmak üzere toplam 260.000'in üzerinde mübadilin yerleştiği Marmara Bölgesi ilk sırada yer almaktadır. İskân edilen toplam mübadillerin yarısından fazlasına (\%58) ev sahipliği yapan Marmara Bölgesini sırasıyla Ege Bölgesi (\%13), Karadeniz Bölgesi (\%11), İç Anadolu Bölgesi (\%10) ve Doğu Anadolu Bölgesi $(\% 2,5)$ izlemiştir. Güneydoğu Anadolu Bölgesi $(0,5)$ ise mübadil iskânından en az pay alan coğrafi bölge olmuştur (Erdal, 2006: 352).
İskân edilen mübadillerin Marmara Bölgesi'nde yoğunlaşmasında yukarıda sayılan sebeplerin dışında serbest bırakılan mübadillerin bu bölgeyi tercih etmesi de etkili olmuştur. “Marmara Bölgesi'ne, özellikle de İstanbul'a, 1924 y1lından itibaren serbest iskân da yapılmıştır. İş bulmak ya da aile fertlerinin yanına taşınmak gibi nedenlerle diğer şehir ve köylerden İstanbul'a doğru gerçekleşen serbest göç hareketleri, İstanbul'da ikamet eden mübadil sayısını arttırmıştır” (Goularas, 2012: 132).

Türk-Yunan mübadelesi kapsamında 1923-1933 yılları arasında ülkemizde 384.000 mübadil iskân edilmiştir (Geray, 1962: 7). Ancak iskân çalışmaları sonucunda mübadillerin önemli bir kısmının amaca uygun iskân edilemediği görülmektedir. Bazı mübadiller meslekleri ile uyumlu olmayan yerlere iskân edilirken; bazı şehirli mübadiller kırsal bölgelere, tarımla uğraşan bazı mübadillerse şehirlere yerleştirilmiştir. Bazı köylerde ise kapasite azlığı nedeniyle aile fertlerinin bir kısmı başka yerlerde iskân edilmiş ve bu durum da ailelerin bölünmesine neden olmuştur (Kaplanoğlu, 1999: 82). Bu nedenle istedikleri yaşam alanına ulaşmaya çalışan Türk mübadillerin ülke içindeki göç hareketleri bir süre daha devam etmiştir. Bu yüzden "devletin iskânından vazgeçip başka yerlere göçen bu mübadiller, iskân yardımı ve üretici hale gelmelerini sağlayacak devlet yardımından faydalanamamışlardır" (Goularas 2012: 134). Ayrıca göçmenlerin alışık olmadığı bölgelere yerleştirilmiş olması toplumsal sorunların yanı sıra ekonomik anlamda da önemli kayıplara neden olmuştur. Örneğin tütün üretimi yapan bazı mübadiller, tarımsal faaliyetin sürdürülebilmesi için gerekli koşullara sahip olmayan sahalara yerleştirilmiştir. Yunanistan'da buğday üretimi yapan bazı mübadillere ise zeytin veya üzüm bağları verilmiş ve onlar da alışık oldukları tarımsal faaliyeti sürdürebilmek için bu alanları buğday tarlalarına dönüştürmüştür (Sezer, 2012: 22-23). 
Görüldüğü üzere Türkiye'ye gelen mübadillerin hepsinin yaşam ve üretim tarzlarına uygun yerlere iskân edilememesi nedeniyle uygulamanın tam anlamıyla başarıya ulaştığını söylemek mümkün değildir. ${ }^{9}$ Bunun nedenleri arasında Mübadele, İmar ve İskân Vekâleti'nin son vekili olan Refet Bey'in de dile getirdiği gibi "vekâletin sürekli olarak el değiştirmesinin etkili işleyişi engellemesi" (Onur, 2006: 228) başta gelmektedir. Ayrıca "Vekâlet memurlarının ihtisas sahibi olmayan diğer vekâlet memurlarından oluşması, mahalli memurlarla vekâlet memurları arasında sağlıklı bir diyalogun kurulamaması, vilâyet memurları ile vekâletin mıntıka memurları arasında yetki çekişmesi gibi sebeplerden dolayı" (Zekai, 2015: 1463 ) istenilen başarı sağlanamamıştır.

Yukarıdaki olumsuz örneklerin yanında, "terk edilen Rum köylerine veya boş arazilere köy kurulması şeklinde gerçekleştirilen iskânlar ise devamlılık açısından olumlu sonuçlar vermiştir. Bu tip iskândan faydalanmış olan mübadiller, gelmiş oldukları çevredeki toplumsal kültürlerini yeni ortamlarında kurdukları köylerine" aktarmışlardır (Boran, 1945: 25-26). Ancak mübadillerin sahip olduğu bu kültürel farkl1lıklar, onları "Türk toplumuna karşı bazen yabancı kılmıştır. Bu nedenle Türkiye'ye geldikten sonraki en önemli sorunlardan biri de kültürel" (Kaplanoğlu, 1999: 127) alanda etkisini göstermiştir. Mübadiller bir yandan yeni yerleştikleri bölgelerin kültürüne uyum sağlamaya ve benzemeye çalışırken diğer yandan da kendi kültürel özelliklerini korumaya çalışmıştır. Bu sürecin uzunluğu ise mübadillerin karşılaştığı ekonomik, sosyal ve kültürel şartların etkisine göre değiş̧iklik göstermiştir.

Türk-Yunan mübadelesinin uygulayıcı taraflar için geçerli sonuçları yanında uluslararası alanda da yansımaları olmuştur. "Zorunlu göçü hukuken meşru bir politika aracı haline getiren bu olay, diğer devletlerin de uygulayacağı bir örnek teşkil etmiş̧tir. 1944 yilında Polonya ve Sovyetler Birliği, 1946 y1lında da Çekoslovakya ve Macaristan arasında gerçekleştirilen nüfus mübadeleleri, Türk-Yunan mübadelesini örnek almıştır" (Bozdağl1, 2014: 30).

\section{SONUÇ}

Osmanlı İmparatorluğu'nun 19. Yüzyıldaki toprak kayıplarına bağlı olarak Anadolu'ya sürekli göçmen akışının yaşanması, Türkiye'ye gelen göçmenleri iskân etme ve yönetme konusunda önemli tecrübeler kazandırmıştır. Ayrıca Lozan mübadillerinin özel bir anlaşma çerçevesinde ve hükümet politikalarına bağlı olarak iskân edilmesi de bu sürece katkı sağlamıştır. Ancak giden göçmenlerin nitelikleri ve ülke ekonomisindeki değerleri göz önüne alındığında Türkiye'nin ciddi bir kayba uğradığı da bir gerçektir. Çünkü Türkiye'den Yunanistan'a göçen Rumlar ağırlıklı olarak ticaretle uğraşan şehirli nüfusu oluştururken, Yunanistan'dan Türkiye'ye göçen Türkler, tarımla uğraşan köylü nüfusu oluşturmaktaydı. Türk tarafı için bir kayıp olan bu durum her ne kadar Yunan tarafı için bir kazanım olarak gözükse de ülke nüfusunun görece az ve ekonomik sorunların da fazla olması nedeniyle Yunanistan'a gelen göçmenlerin hayatını zorlaştırmıştır. $\mathrm{Bu}$ duruma Yunanistan'ın toplu iskân politikası uygulamasından duyulan rahatsızlıklar da eklenince göçmenler, bir yandan ülke içinde yer değiştirdikleri gibi diğer yandan çeşitli Avrupa ülkeleri ve ABD’ye yönelerek yeni bir göç dalgası daha başlatmışlardır.

Lozan nüfus mübadelesi dönemin güvenlik ve politik şartları düşünüldüğünde azınlıklar sorununun çözülmesi bakımından bedelini devletlerin ve milletlerin ödediği zaruri ve başarılı bir uygulamadır. Türkiye ve Yunanistan'ın azınlıklardan kurtulma çabasının ve ulus devlet olma isteğinin bir sonucu olarak ortaya çıkan mübadele sayesinde taraflar, süreç sonunda dinsel kimlik anlamında bütünlük sağlama imkânına kavuşmuştur. Ancak Türkiye'deki Rum ve Yunanistan'daki Türk azınlığı göçmen hâline getiren mübadele, her iki ülkedeki mübadillerin hayatlarını kökünden değiştirmiş ve yaşanılan sıkıntıların etkisi günümüze kadar süregelmiştir. Bu durum her iki ülkedeki azınlığın nüfus gelişimini de etkilemiş ve yaşadıkları ülkeleri terk etmelerine neden olmuştur.

Türkiye ve Yunanistan'daki azınlıklar, nüfus miktarlarındaki değişimlerden de anlaşıldığ sıkıntılar yaşamıştır. Bir yandan yerleştikleri yerlere uyum sağlamaya çalışan mübadiller diğer yandan da geçmişlerinden kopmamaya gayret etmişlerdir. Türkiye'de iskân edilen mübadiller de geçmişten bugüne kültürel değerlerini ve kimliklerini yaşatmaya çalışmaktadır. İlk dönemlerde köy kahveleriyle başlayan geçmişle olan bağın korunması çabası, günümüzde dernekler ve vakıflar gibi çeşitli sivil toplum örgütlerinin yanı sıra sanal ortamda da devam ettirilmeye çalışılmaktadır.

Finansal Destek: Yazar bu çalışma için finansal destek almamıştır.

9 Celal Bayar, bu durumun nedenini TBMM'de yaptığı konuşmada gidenlerin çoğunun esnaf ve şehirli, gelenlerin çoğunun ise reçber ve köylü olması ile açıklamıştır. Daha fazla bilgi için bkz: (Sezer, 2012). 


\section{KAYNAKLAR}

ABTTF (Avrupa Batı Trakya Türk Federasyonu). (2019). Demografik Yapısı, Erişim adresi: https://www.abttf.org/html/index. php?link=detay\&id=19\&arsiv $=1 \&$ typ $=1$

Arı, K. (1995). Büyük Mübadele: Türkiye ye Zorunlu Göç (1923-1925). İstanbul: Tarih Vakfi Yurt Yayınları.

Arı, K. (2012). Büyük Mübadele: Türkiye’ye Zorunlu Göç (1923-1925). 6. Basım, İstanbul: Tarih Vakfı Yurt Yayınları.

Babuş, F. (2016). Osmanlı'dan Günümüze Etnik-Sosyal Politikalar Çerçevesinde Göç ve İskân Siyaseti ve Uygulamaları. İstanbul: Ozan Yayıncilık.

Behar, C. (1996). Osmanlı Imparatorluğu ve Türkiye'nin Nüfusu (15001927). Ankara: Devlet İstatistik Enstitüsü Yayınları.

Belli, M. (2006). Türkiye-Yunanistan Nüfus Mübadelesi, Ekonomik Açıdan Bir Bakış. İstanbul: Belge Yayınları.

Bıyıklığlu, T. (1987). Trakya'da Milli Mücadele, C.I. Ankara: TTK Yayınları.

Blanchard, R. (1925). The Exchange of Populations between Greece and Turkey. Geographical Review 15: 449-456.

Boran, B. (1945). Toplumsal Yapı Araştırmaları (İki köy çeşidinin mukayeseli tetkiki). Ankara: Türk Tarih Kurumu Yayınları.

Bozdağlı, Y. (2014). Türk-Yunan Mübadelesi ve Sonuçları. TSA Yı1:183: 9-32.

Budak, Ö. (2010). Mübadele Meselesi ve Lozan'da Çözümü. Karadeniz Araştırmaları Dergisi 26: 129-142.

Erdal, İ. (2006). Mübadele: Uluslaşma Sürecinde Türkiye ve Yunanistan 1923-1925. İstanbul: IQ Kültür Sanat Yayınları.

Erdoğan, M. ve Kaya, A. (2015). Türkiye'nin Göç Tarihi: 14. Yüzyıldan 21. Yüzyıla Türkiye’ye Göçler. İstanbul: İstanbul Bilgi Üniversitesi Yayınları.

Eryılmaz, B. (1992). Osmanlı Devletinde Millet Sistemi. İstanbul: Ağaç Kitabevi.

Geray, C. (1962). Türkiye'den ve Türkiye'ye Göçler ve Göçmenlerin İskânı (1923-1961). Ankara: Ajans-Türk Matbaas1.

Goularas, G. (2012). 1923 Türk-Yunan Nüfus Mübadelesi ve Günümüzde Mübadil Kimlik ve Kültürlerinin Yaşatılması. Alternatif Politika Dergisi Cilt: 4, Say1: 2: 129-146.
Güner, Z. (2015). Türkiye-Yunanistan Nüfus Mübadelesinde Türkiye Cumhuriyeti Devleti'nin İskân Politikast. Uluslararası Asya ve Kuzey Afrika Çalışmaları Kongresi ICENAS 38, 10-15: 1453-1466. Herkül, M. (2014). Göç: Rumların Anadolu'dan Mecburi Ayrılışı (1919-1923). İstanbul: Küçük Asya Araştırmaları Merkezi.

İskân Tarihçesi. (1932). İstanbul: Hamit Matbaası.

Kaplanoğlu, R. (1999). Bursa'da Mübadele. Bursa: Avrasya Etnografya Vakfi Yayınları.

Kodaman, Ö. (2008). Türkiye İle Yunanistan Arasında Nüfus Mübadelesi. (Yüksek Lisans Tezi). Kahramanmaraş Sütçü İmam Üniversitesi, Kahramanmaraş.

Ladas S. P. (1932). The exchange of minorities Bulgaria, Greece and Turkey. New York: The Macmillan Company.

Macar O.D. ve E. Macar. (2010). Beyaz Rus Ordusu Türkiye'de. İstanbul: Libra Yayınları.

Milliyet Gazetesi.(2012). “Böyle Giderse Türkiye'de Rum Kalmayacak”, Erişim adresi: http://www.milliyet.com.tr/gundem/boyle-giderseturkiyede-rum-kalmayacak-1639664,

Oran, B. (ed.) (2002). Türk Dış Politikası: Kurtuluş Savaşından Bugüne Olgular, Belgeler, Yorumlar. İstanbul: İletişim Yayınları.

Öksüz, H. (2000). Türk-Rum Nüfus Mübadelesinin Sebep ve Bazl Ístisnaları. Atatürk Araştırma Merkezi Dergisi, Cilt 16, Sayı 48: 753-769.

Önder, S. (2000). 1913 Türk-Bulgar Mübadelesi, Yeni Türkiye Dergisi, No:31: 342-346.

Sezer, S. (2012). Lozan ve Mübadele, İstanbul: İstanbul Kültür Üniversitesi Atatürk ilkeleri ve İnkılâp Tarihi Araştırma ve Uygulama Merkezi Yayınları.

Soysal, İ. (2000). Türkiye’nin Siyasal Antlaşmaları. Ankara: Türk Tarih Kurumu Yayınlar1.

Tan, G. (2014). Istanbul'da Rumlar ve Paskalya, Erişim adresi: https:// www.bbc.com/turkce/haberler/2014/04/140428_istanbul_paskalya

T.C. Dışişleri Bakanlığı. (2019). Yunanistan'daki Türk Varlığı, Erişim adresi: http://www.mfa.gov.tr/bati-trakya-turk-azinligi.tr.mfa

Yıldırım, O. (2016). Diplomasi ve Göç: Türk-Yunan Mübadelesi’nin Öteki Yüzü. İstanbul: İstanbul Bilgi Üniversitesi Yayınları.

Zürcher, E.J. (2003). Greek and Turkish Refugees and Deportees 1912 1924. Erişim adresi: http://www.transanatolie.com/english/turkey/ turks/Ottomans/ejz18.pdf. 